\title{
SCHOOL REFORM MEASURES OF 1931-33 IN THE CENTRAL BLACK EARTH REGION
}

\author{
Andrey Zlobin \\ Candidate of Historical Sciences, Associate Professor, Voronezh State University of Engineering \\ Technologies, Revolution Avenue,19, Voronezh, Russia, E-mail: anzlobin@bk.ru
}

\begin{abstract}
In the article, on the basis of archival documents introduced into scientific circulation for the first time, various aspects of the reform of school education in the Central Black Earth Region in the early 1930s are investigated. This work examines the introduction into the educational process of such innovations initiated by the party authorities as the rejection of the "project method" and the "brigade-laboratory" method, the introduction of a classroom system, a fixed timetable, transfer tests and individual reporting of schoolchildren. Attention is focused on school construction and supply, issues of organizing training and professional development of teachers. The author examines measures aimed at introducing the principles of polytechnism into education, provides data on changes in the student population and the quality of education over the years of the reform.
\end{abstract}

Keywords: educational reform, teacher, Soviet school, quality of education, students.

\section{INTRODUCTION}

In 1931, the next stage of reforming the Soviet secondary education system began. The reform of the school is connected with the directive of the XVII Party conference on the construction of a classless society during the second five-year plan. the school was perceived by Soviet ideologists as one of the tools of communist construction. The existing system, built in the 20s XX century no longer suited the top Soviet leadership, since it was not able to provide the growing and rapidly industrializing Soviet economy with the required number of specialists of a decent level.

The main reason for the low quality of education was the widespread introduction of the brigade-laboratory method and the method of projects that did not provide for the personal responsibility of the student, there was no personal test of knowledge and, in modern terms, was actually replaced by the formation of abstract competencies aimed at the ability to work in a team, to search for and systematize information. In practice, this approach led to the fact that one or two people in the training team performed tasks, mastered the material, and the rest, who played the role of extras, received the same qualification diploma.

On July 25, 1930, the Central Committee of the All-Union Communist Party of Bolsheviks adopted a resolution "On universal compulsory primary education", according to which universal compulsory primary education for children aged 8-10 years, as well as universal compulsory education in the volume of school seven-year plans in industrial cities, factory districts and workers' settlements.

The relevance of studying the experience of reforms covering various aspects of the educational process is explained by direct parallels with the modern stage of development of the education system in Russia, which, as in the early 1930s, is in a state of permanent reform. The study of the previous experience of reforms, successful and unsuccessful experiments is a prerequisite for understanding the historical roots of Russian education, it can serve as a warning, both for repeating the mistakes of the past and for making new ones. 


\section{METHODOLOGY}

The main source of the research is, first of all, materials from the State Archive of the Socio-Political History of the Voronezh Region. Many archival materials are introduced into scientific circulation for the first time.

An important source of information is also the materials of the regional journal "Cultural Front of the Central Black Earth Region", which highlighted materials related to changes in the organization of the educational process and in the methodology of the disciplines taught.

The originality of this study is explained by the fact that the development of school education in the Central Black Earth Region has not previously been the subject of independent research. Certain points touching upon this issue were highlighted in works devoted to the development of education in the USSR, in works dedicated to the People's Commissar of Education A.S. Bubnov.

Comparison with the results of these studies allows us to trace the general trends and identify the features of the implementation of the educational reform in the CCE.

Western scholars made a notable contribution to the study of Russian education in the 1930s. In general, being critical of the class approach and communist ideology, they positively assess the results of the reforms carried out by the Stalinist administration, note the scale of the goals and changes achieved, as well as the relevance of using the pre-revolutionary experience in reforming the Soviet education system.

\section{DISCUSSION}

The aim of the work is to study the regional experience of implementation, initiated by the state in the early 1930 s, of innovative changes in school education, research of changes in the education system of schoolchildren, analysis of its quantitative and qualitative characteristics.

The tasks of the article include: studying the legislative framework of the reform, studying the specifics and results of the reforms being introduced, comparing with changes in school education in other regions of the country, clarifying the features of the development of education in the Central Black Earth Region.

The main provisions of the reform were based on the decisions of the Central Committee of the All-Union Communist Party of Bolsheviks dated 05.09.1931 "On primary and secondary school", dated 25.08.1932 "On curricula and the regime of primary and secondary schools" and from 14.02. 1933 "On textbooks for primary and secondary schools."

Of great importance were the decisions of the Board of the People's Commissariat of Education, including from 09/05/1931 "On the main directions of building programs for primary and secondary schools", the resolution of the Collegium of the People's Commissariat of Education of the RSFSR, including from October 18,1931 on the creation of and the cities of the model schools network.

In the Decree of the Central Committee "On primary and secondary schools," it was pointed out that the fundamental drawback of the existing education system is that "education at school does not provide a sufficient amount of general education knowledge and unsatisfactorily solves the problem of preparing quite literate people for technical schools and for higher education who are good at Fundamentals of Sciences ", noted the importance of polytechnization of education in the context of the solid assimilation of such sciences as physics, chemistry, mathematics, the need to introduce carefully developed curricula and plans into the educational process, the importance of establishing firm timetables. The decree notes the detrimental consequences of the introduction of untested teaching methods, including the "project method", which, as it was emphasized, stemmed from the "anti-Leninist theory of the withering away of the school" and actually led to the destruction of Soviet education.

In order to improve the quality of education, the decree prescribed the creation of a network of exemplary schools, which the regional authorities should put in the most favorable position in terms of supply and concentrate the best teaching staff in them. The resolution gives instructions on organizing the training of teaching staff and on increasing teachers' salaries, emphasizing the importance of a differentiated approach in remuneration of teachers.

\section{RESULTS}

In the Decree "On curricula and the regime of primary and secondary schools" of 1932, some positive aspects of the new curricula were noted and at the same time indicated their significant shortcomings: overload with educational material, lack of intersubject connections, in some cases simplification and the presence of methodological and scientific errors, lack of historicism in teaching social sciences. In addition 
to detailed clarification and analysis of curricula, it was ordered to eliminate the distortions of the "laboratoryteam" method, and to organize the educational process in the form of lessons "with a strictly defined schedule of classes and a solid composition of students." An important innovation was the introduction of current individual systematic control of the knowledge of each student. Teachers were instructed at the end of the quarter to draw up a characteristic of the progress of each student. At the end of the year, verification tests were established for all students.

For 1931-1933. 13,916 school buildings were repaired, 5527.8 thousand rubles were invested in repairs.

The construction of large schools was a tendency typical for many regions of the country, for example, in Moscow "the largest schools, palace schools for 4.5 thousand students grew up. These schools occupied huge, bright, comfortable buildings with special classrooms, workshops, laboratories, living corners, with wonderful recreational and physical culture halls, with meteorological towers and children's stadiums near schools. "

The schools of the Central Black Earth District were poorly provided with furniture, and the existing ones in large part required replacement, as of little use. The situation with fuel was not good. In the surveyed in 1933,75 districts out of 6516 schools were fully provided -1069 , below $50 \%-2402$ schools, had no fuel at all - $1284(19.7 \%)$.

The schools of the Central Black Earth Region were sorely lacking notebooks. Students often wrote on random scraps. One notebook was conducted in several disciplines. There were extremely few didactic materials: wall tables, drawings, materials from newspapers and magazines were practically not used. This was explained, among other things, by the fact that local budgets often did not allocate sufficient funds for these needs.

School libraries were very weak. There were 577 school libraries in the region. On average, each library had between 500 and 5,000 books. There were only 20 books in the Olkhovatsk 1 st grade school. There was a lack of literature necessary to work out the program material.

Following the instructions of the Central Committee of the All-Union Communist Party (Bolsheviks) on the polytechnization of educational institutions, education leaders in the Central Black Earth Region took measures aimed at increasing the number of workshops and work rooms, a large number of tools and equipment were purchased.

A big hindrance in the work of workshops and work rooms was the lack of training of labor instructors in the second concentrate (stage), as well as teachers of the first concentrate. A significant number of schools have entered into contracts with industrial enterprises and collective farms on the issue of sponsorship. According to $80 \mathrm{FZS}$, as a result of the fulfillment of contracts between schools and enterprises, 150 vices, 120 workbenches, over 200 sets of locksmith tools were allocated by enterprises for equipping workshops. Engineering and technical workers of enterprises, collective farms, state farms and MTS provided assistance to the school, in many schools they worked for free and voluntarily as instructors.

School plots began to be used as a base for polytechnics in the form of subsidiary plots. The good organization of school facilities allowed some schools to provide students with hot breakfasts.

Of the 11124 schools surveyed in 1933,9649 schools (86.7\%) were provided with land plots. The entire area of school land plots was equal to 29657 hectares.

A big problem in the, as well as throughout the country, was the lack of teachers, their low qualifications and overloading. In the primary school in 1933 there were 29765 teachers against 18171 in the 1929-30 academic year. In secondary school, respectively, 10339 versus 4551 . In the 1933-34 academic year, 40\% of teachers with lower education and short-term pedagogical training worked in elementary schools, $34.1 \%$ with experience from 1 to 3 years. In secondary school, $10 \%$ of rural teachers and $5.5 \%$ of urban teachers had a lower education. Among the teachers of secondary schools in the village, only $6 \%$ had higher education, $13 \%$ had incomplete higher education. In urban secondary schools, $21.1 \%$ of teachers had a higher education, and $13.9 \%$ had incomplete higher education.

If we take the entire staff of the teaching community, then $13.7 \%$ of rural teachers had work experience of up to 1 year, $5.5 \%$ of urban teachers, $29 \%$ of rural teachers and $13.7 \%$ of urban teachers had work

\section{CONCLUSION}

The development of school education in the Central Black Earth District generally corresponded to the trends that took place in other regions of the country. The peculiarities of the region, which left their mark on the 
development of education, were its agricultural character and intensive migration from the village devastated by collectivization to the industrializing cities. A specific feature of the region was also a low start, from which the educational system began its intensive development. In the peripheral, agrarian region, in contrast to areas with developed university traditions, in fact, there was no school for training teachers. This circumstance, along with financial and managerial difficulties, explains many of the difficulties of the transition phase. But nevertheless, in spite of any obstacles, the school education of the Central Black Earth Region has achieved serious success.

As a result of the universal seven-year education introduced in 1931 in the spring of 1934, 90 thousand people were graduated from 7 groups (classes) of schools in the Central Black Earth District, while in the year of the introduction of seven-year education, only 16,500 people were graduated from the seven-year school. Most of those graduated from the seven-year plan went directly to production, to collective and state farms, preschool workers, secretaries, etc. In 1935, about 160 thousand people were released from the seven-year plan. In terms of enrollment in an advanced school, in terms of graduation from the seven-year period, the Central Black Earth District took first place in the Union.

From 1931 to 1934 the number of teachers and their qualifications increased. At the same time, the problem of shortage and low qualifications of teachers was not resolved and along with other problems and shortcomings moved to the next stage of the reform.

Many schools were still poorly equipped, there was not enough space, fuel, notebooks, textbooks, and overcrowded classrooms remained a frequent occurrence. Not all educational institutions have switched to fixed schedules and stable work plans. The lack of teachers often led to disruptions in teaching certain disciplines.

The introduction of individual systematic daily accounting of students' knowledge, tests, quaternary characteristics, verification and final tests, a system of succession of levels and stages of education increased the quality of education, helped to overcome the "fundamental shortcoming" of the Soviet school of the 20s and significantly improved the quality of those entering secondary and higher professional educational institutions.

\section{REFERENCE LIST}

Ashmarov I.A. (2019) On the question of the characteristics of the intelligentsia. Society and Power: History and Modernity. Materials of the 13th Regional Scientific Conference. Voronezh: Voronezh State University. Pp. 449-452. (in Russ).

Ashmarov I.A., Bobrovnikova M.A., Volkova E.A. (2016) On state policy in the field of regional education. Region: systems, economics, management. No. 2 (33). Pp. 90-97. (in Russ).

Ashmarov I.A., Volkova E.A., Frolova E.V. (2015) On the formation of trends in the higher education system in the framework of modern globalization processes. Modern problems of science and education. №. 1-1. P. 975. (in Russ).

Avdiev V. (1942) Teaching general history in high school during the Patriotic War against German fascism. Historical journal. №. 3-4. Pp. 122-129. (in Russ).

Butyagin A. S., Saltanov Yu. A. (1957) University education in the USSR. 296 p. (in Russ).

Ershov B. A., Semenkova E. V. (2016) The consequences of the collapse of the Soviet Union. International Journal of Humanities and Natural Sciences. № 3. Pp. 20-22. (in Russ).

Ershov B.A. (2010) The Russian Orthodox Church and secular power in the Voronezh province in the XIX early XX centuries. GOU VPO "Voronezh State Technical University". Voronezh. 167 p. (in Russ).

Ershov B.A. (2010) The system of spiritual education in Voronezh province in the 19th century. Education and Society. №. 5 (64). Pp. 105-108. (in Russ).

Ershov B.A., Fursov V.N. (2018) The Russian Church in the State Mechanism of Russia. Bulletin SocialEconomic and Humanitarian Research. № 1. Pp. 32-37. (in Engl).

Ershov B.A., Mukhina N.E., Ashmarov I.A. (2018) Russian state policy in the field of culture: X-XX centuries. Article in the open archive No. 10.15146 / R3566F 04.06.2018. (in Engl). 
Ershov B.A., Perevozchikova L.S., Romanova E.V. (2019) Globalization and Intensification of Spiritual Values in Russia in the Philosophical Aspect. 6th International Conference on Education and Social Sciences Abstracts \& Proceedings. Pp. 208-212. (in Engl).

Ershov B.A., Volkova E.A., Frolova E.V., Volkov N.M., Pletnev V.I. (2019) The Revolution of 1905-1907. in Russia: results and consequences. 6th International Conference on Education and Social Sciences. Abstracts \& Proceedings. Pp. 213-220. (in Engl).

Feofanov M. P. (1941) Soviet schoolchildren in defense work. Soviet pedagogy. №. 10. Pp. 43-49. (in Russ).

Gittis I. V. (1940) Initial training in history. Essays on the methodology of teaching history. L.: Uchpedgiz. 244 p. (in Russ).

Kalashnikolv A. G. (1946) On the tasks of the school in the 1946-1947 academic year. Report at the AllRussian Meeting on Public Education on August 5-9. Soviet pedagogy. №. 10-11. Pp. 9-27. (in Russ).

Kinkulkin A. T., Lerner I. Ya. (1961) A new stage in the development of school historical education. Voprosy Istorii. №. 7. Pp. 6-20. (in Russ).

Pavlenko N. I. (1991) Historical Science in the past and present (some reflections aloud). History of the USSR. №. 4. Pp. 81-93. (in Russ).

Romanova E.V., Perevozchikova L.S., Ershov B.A. (2017) The Lifestyle of the Human Being in the Information Society. 3rd International Conference on Advances in Education and Social Sciences Proceedings of ADVED Pp. 950-954. (in Engl).

Timofeeva E. G. (2002) State policy in the field of social science education of Russian youth in the 50s and 90 s of the XX century. M. Prometey. 366 p. (in Russ).

Zhitkova S. A. (2007) State policy in the sphere of public education and its implementation in the Russian Federation in 1928-1941: on the materials of the Lower Volga region: author's abstract. candidate of Historical Sciences. 23 p. (in Russ). 